\title{
A LÁVA A FÖLD MAGJÁBÓL SZÁRMAZIK, VAGY MÉGSEM - NÉHÁNY LEMEZTEKTONIKÁHOZ KAPCSOLÓDÓ TÉVKÉPZET ÖSSZEHASONLÍTÓ ELEMZÉSE
}

\author{
LAVA ORIGINATES FROM THE EARTH'S CORE, DOESN'T IT? A COMPARATIVE ANALYSIS OF SOME \\ PLATE-TECTONICS-RELATED MISCONCEPTIONS
}

\author{
KÁDÁR ANETTª - FARSANG ANDREA ${ }^{\text {bj }}$ \\ Szegedi Tudományegyetem Földrajzi és Földtudományi Intézet \\ a kdr.anett@gmail.com, ${ }^{\mathrm{b}}$ farsang@geo.u-szeged.hu
}

\begin{abstract}
The international research of geographical misconceptions is enormous compared to its Hungarian counterpart. The abundance of the literature and also the different kinds of misconceptions encouraged us to start our project of revealing geographical misconceptions in Hungary. Our present study aims at identifying plate-tectonics-related misconceptions of three distinctive groups of students: Grade-9 secondary grammar school students, Geography BSc students, and BA students of different academic interests. We employed a cross-case-based approach, and multiple kinds of data were collected for triangulation. A three-part diagnostic test was administered to students, and results were evaluated by comparative content analysis. We found that while culturally induced misconceptions were not present, mistakes in textbooks, the linguistic characteristics of the Hungarian language, the extensive media coverage of certain topics, and informal learning are most likely to be responsible for the emergence of geographical misconceptions. We argue that primary, secondary, and tertiary education should move to a more practical, innovative, and inclusive pedagogy where geographical knowledge is organically anchored into everyday life in order to refute possible misconceptions.
\end{abstract}

Keywords: geographical misconceptions, conceptual change, plate tectonics, problem-oriented teaching

\section{Bevezetés}

Egyetemi oktatóként és középiskolai tanárként is egyaránt találkozunk azzal, hogy egy-egy földrajzi jelenséghez, fogalomhoz, folyamathoz kapcsolódóan olyan értelmezéseket, magyarázatokat kaptunk egy-egy vizsga, dolgozat vagy felelet során, amelyek teljesen ellentmondanak mindannak, amit mi gondosan megtanítottunk. Többször előfordul, hogy a válaszok nem egyszerủen pontatlanok, hanem tudománytalanok, vagy éppen áltudományosak, a napi híreket emelik be tényanyagként, esetleg saját megfigyelésen alapulnak anélkül, hogy a már megtanult földrajzi ismeret gyakorlati alkalmazása jelenne meg bennük. Szakirodalmi kutatásaink alapján kijelenthetjük, hogy e hibák egyik lehetséges oka az, hogy diákjainknak egy-egy adott földrajzi jelenség kapcsán tévképzeteik vannak. Cikkünk első részében a tévképzetek jellemzőit, kialakulásuk lehetséges okait, nemzetközi és hazai szakirodalmi hátterét mutatjuk be. Ezt követően 
azt vizsgáljuk meg, milyen tévképzeteik lehetnek középiskolai tanulóknak és egyetemi hallgatóknak, továbbá azt, hogy ezek a tévképzetek milyen kapcsolatban állnak a földrajzi ismereteket biztosító információforrásokkal.

\section{A tévképzet fogalma és értelmezési nehézségei}

A tévképzetekkel kapcsolatos vizsgálatok az ún. fogalmi váltás kutatásához kapcsolódnak. A fogalmi váltás kifejezést KuHN, T. (1962) használta először, és arra utal, hogy egy adott tudományos elméletbe ágyazott fogalom jelentése akkor változik meg, ha maga az a paradigma megváltozik (VosniAdou, S. et al. 2008). A fogalmi váltás a pedagógiai és a pszichológiai szakirodalomban a fogalmak tanulásával, az ismeretelsajátítás módjaival, a tanulók ismeretszerkezetének megismerésével és változásaival foglalkozó kutatási irány. Két fő megközelítése közül a tanuláselméleti irány magát a tanulást értelmezi fogalmi váltásként, a kognitív fejlődéspszichológiai irány pedig a régi és az új ismeretek kölcsönhatását, változását és módját vizsgálja (Korom E. 2000). A fogalmi váltást vizsgáló kutatások az évtizedek során a folyamatnak mindig egy újabb vagy más aspektusát helyezték előtérbe. Ebből következően ma a fogalmi váltást maguk a kutatók is rendkívül széleskörűen és változatosan definiálják és jellemzik (Pfundt, H. - Duit, R. 2009; Pozo, J. I. 1997; Murphy, P. K. - Alexander, P. A. 2008; Vosniadou, S. et al. 2008).

Az óvodás és kisiskolás korú gyerekek ismeretei elsősorban még saját tapasztalataikból, mindennapi megfigyeléseikből származnak. Ezeket úgy szervezik egy számukra egységes és koherens egészbe, ahogy azt ők a saját koruknak megfelelően értelmezni tudják. Később a formális, az iskolai tanítás-tanulás folyamata során ebbe a fogalmi struktúrába új elemek épülnek, amelyek vagy logikusan kapcsolódnak a már meglévő ismeretekhez, vagy felülírják azokat, és ezzel megváltoztatják (pontosítják) a már meglévő fogalmi hálót. Ekkor beszélünk fogalmi váltásról. De ha az új információ elszigetelten marad meg ebben a fogalmi hálóban, és nem tudja felülírni a már ott található fogalmi kapcsolatokat, akkor a fogalmi váltás nem sikeres, és ez vezethet tévképzetek kialakulásához, amely később befolyásolja az adott tantárgy elsajátításának sikerességét (Korom E. 1999, 2000, 2002, 2005; Murphy, P. K. Alexander, P. A. 2008; National Research Council, 1997). Tehát többek között mi tanárok vagyunk azok, akiknek adott esetben azt kell „felülírni”, hogy „a mag mozgása okozza a kontinensvándorlást", és ennek sikerességét a szakmai felkészültségünkön túl több tényező is befolyásolja. 
A fogalmi váltást egyaránt jellemzik lentről felfelé építkező tanulási folyamatok, amelyek implicit és additív módon szerveződnek, illetve fentről lefelé építkező, explicit módon szerveződő folyamatok. Implicit tanulás során a gyerekek nem tudatosan tanulnak, mint az iskolában, hanem „maguktól”, a környezetükben általában spontán megfigyelt, látott, hallott információt építik be az ismeretrendszerükbe, illetve az ismeretrendszerüket alakítják úgy, hogy a tapasztalataik szervesen beépülhessenek a fogalmi hálójukba. Ez egy időigényes folyamat, jellemzően ilyen például az anyanyelv elsajátítása vagy az élő és élettelen dolgok kategorizálása. Ezzel szemben az explicit tanulás során egy viszonylag rövid idő alatt a gyerekek szándékos külső hatásra (tanár és tanítás) szembesülnek egy-egy új ismeretelemmel, amelyet be kell valahogyan építeni az ismeretrendszerükbe anélkül, hogy az implicit tanulás során rendelkezésükre álló bőséges idő meglenne. Mindkét tanulási mód eredményezhet fogalmi váltást, és mindkét esetben előfordulhat, hogy a fogalmi váltás nem tökéletes. A tanulók kognitív struktúrái, mint például a korábbi ismeretekből, tapasztalatokból, hitvilágból, érdeklődési körből, kultúrából és egyéb információforrásokból származó ismeretek jelentősen befolyásolják a fogalmi váltás folyamatát (Korom E. 2000, 2002, 2005; Ross, K. E. K. - SHUELL, T. J., 1990; Vosniadou, S. et al. 2008; Vosniadou, S. - Brewer, W. F. 1992; Samarapungavan, A. et al. 1996). Ha ezeket a már meglévő fogalmi szerkezeteket egy-egy tanítási folyamat megkezdése előtt feltárjuk, akkor képet alkothatunk arról, hogy egy-egy tanuló vagy tanulócsoport milyen fogalmi struktúrával rendelkezik egy adott életkorban, milyen ismeretei, elgondolásai, esetleg tévképzetei vannak, amikor kilencedik osztályosként elkezdi tanulni például a Föld belső szerkezete témakört.

Maga a tévképzet szó nem egységesen használt terminológiai tétel, hanem tanulmányonként más és más meghatározással használják a szerzők attól függően, hogy a tévképzet mely aspektusa hangsúlyos az adott kutatásban. Eddigi szakirodalmi adataink alapján azt állapítottuk meg, hogy nincs olyan általánosan elfogadott definíció, amely a tévképzet összes fö jellemzőjét magába foglalná. Ezért egy táblázatban foglaltuk össze azokat a föbb csoportokat, amelyeket tanulmányunkban használunk (1. táblázat).

Az 1. táblázatban található általános tévképzet fogalomként használt meghatározás bármilyen életkorú ember esetében használható, mivel a fogalmi váltás sikertelenségét és az ennek következtében megjelenő fogalmi szerkezet mindenkire általánosan érvényes sajátosságait jellemzi. A specifikus tévképzet-típusok azonban nem egyformán és nem szükségszerüen jelentkeznek a gyerekeknél és a felnőtteknél. Bárkinek lehetnek prekoncepciói vagy populáris tévképzetei, de sosem feltétlenül ugyanazok, mivel a tévképzetek 


\begin{tabular}{|c|c|c|c|c|}
\hline Típus & Fogalom & Meghatározás & Szinonimák & Források \\
\hline Általános & Tévképzet & $\begin{array}{l}\text { Olyan kognitív struktúrák, amelyek mé- } \\
\text { lyen be vannak ágyazódva egy személy } \\
\text { ismeretrendszerébe, olyan, esetleg túl } \\
\text { korán megtanult, de helytelen, hibás } \\
\text { adatok, fogalmak, amelyek a mai ter- } \\
\text { mészettudományos ismeretekkel ösz- } \\
\text { szeegyeztethetetlenek, oktatással is } \\
\text { nehezen változtathatók meg, még fel- } \\
\text { nőttkorban is jelen lehetnek. }\end{array}$ & $\begin{array}{l}\text { Alternatív } \\
\text { koncepció, } \\
\text { hibás adaton } \\
\text { alapuló } \\
\text { tévképzet }\end{array}$ & $\begin{array}{l}\text { National Research } \\
\text { Council 1997; Korom } \\
\text { E. 2002, 2005; } \\
\text { Dudás E. et al. 2012; } \\
\text { Chang, C. H.- } \\
\text { Pascua, L. } 2015\end{array}$ \\
\hline Specifikus & $\begin{array}{l}\text { Vernakuláris } \\
\text { (köznyelvi) } \\
\text { tévképzet }\end{array}$ & $\begin{array}{l}\text { Egy adott fogalomnak, jelenségnek a } \\
\text { mindennapi nyelvhasználaton alapuló } \\
\text { értelmezése, amikor egy adott szó mást } \\
\text { jelent a hétköznapokban, és mást ter- } \\
\text { mészettudományos kontextusban, ami } \\
\text { egy adott természettudományos foga- } \\
\text { lom, jelenség, folyamat félreértelmezé- } \\
\text { séhez vezethet }\end{array}$ & $\begin{array}{l}\text { Nyelvészeti } \\
\text { tévképzet, } \\
\text { metafora }\end{array}$ & $\begin{array}{l}\text { National Research } \\
\text { Council 1997; Dol- } \\
\text { phin, G.- } \\
\text { Benoit, W. } 2016\end{array}$ \\
\hline Specifikus & Prekoncepció & $\begin{array}{l}\text { Egy adott jelenségnek, fogalomnak a } \\
\text { mindennapi tapasztalatokra alapozott } \\
\text { értelmezése, amely befolyásolja az új } \\
\text { fogalmak és modellek későbbi értelme- } \\
\text { zését, valamint a kognitív struktúrába } \\
\text { történő beépítését. }\end{array}$ & $\begin{array}{l}\text { Alternatív } \\
\text { koncepció, } \\
\text { intuitív } \\
\text { koncepció, } \\
\text { oktatás elốtti } \\
\text { koncepció, } \\
\text { mindennapi } \\
\text { tudás, } \\
\text { gyermeki } \\
\text { tudomány }\end{array}$ & $\begin{array}{l}\text { Vosniadou, S.-- } \\
\text { Brewer, W. F. 1992; } \\
\text { National Research } \\
\text { Council 1997; } \\
\text { Duit, R. et al. 2001; } \\
\text { Nieswandt, M. 2001; } \\
\text { Eryilmaz, A. 2002; } \\
\text { Park, J.- Han, S. } \\
\text { 2002; } \\
\text { Schur, Y. et al. } 2002\end{array}$ \\
\hline Specifikus & $\begin{array}{l}\text { Kulturális } \\
\text { tévképzet }\end{array}$ & $\begin{array}{l}\text { Egy adott fogalomnak, jelenségnek egy } \\
\text { olyan beágyazó kultúrán alapuló értel- } \\
\text { mezése, amely erősen jelen van a min- } \\
\text { dennapokban. }\end{array}$ & $\begin{array}{l}\text { Nem } \\
\text { tudományos } \\
\text { világkép }\end{array}$ & $\begin{array}{l}\text { Vosniadou, S.-- } \\
\text { Brewer, W. F. 1992; } \\
\text { Samarapunga-van, } \\
\text { A. et al. 1996; } \\
\text { Sungur, S. et al. } \\
\text { 2001; } \\
\text { Tsai, C. C. 2001; } \\
\text { Eryilmaz, A. 2002; } \\
\text { Alsparslan, C. et al. } \\
2003\end{array}$ \\
\hline Specifikus & $\begin{array}{l}\text { Populáris } \\
\text { tévképzet }\end{array}$ & $\begin{array}{l}\text { Egy adott fogalomnak, jelenségnek a kor- } \\
\text { társ médián (hírek, filmek, könyvek, képre- } \\
\text { gények, stb.) alapuló értelmezése. }\end{array}$ & & $\begin{array}{l}\text { Barnett, M. et al. } \\
\text { 2006; } \\
\text { Kádár A. et al. } 2015\end{array}$ \\
\hline Specifikus & $\begin{array}{l}\text { Fogalomalko- } \\
\text { tási tévképzet }\end{array}$ & $\begin{array}{l}\text { Az egyes természettudományos tan- } \\
\text { tárgyak tanítása nem idéz elő fogalmi } \\
\text { váltást, az előzetesen kialakult, nem } \\
\text { feltétlenül helyes természettudományos } \\
\text { világkép nem változik meg, a tanulók } \\
\text { hibás modelleket alkotnak egy-egy ter- } \\
\text { mészettudományos jelenségről. }\end{array}$ & & $\begin{array}{l}\text { National Resear- } \\
\text { ch Council, } 1997 ; \\
\text { Eryilmaz, A. 2002; } \\
\text { Chang, C. H.- } \\
\text { Pascua, L. } 2015\end{array}$ \\
\hline
\end{tabular}

1. táblázat. A tévképzetek fogalmainak összesitő táblázata (források a táblázatban megadva) 
kialakulását több tényező - például kultúra, nyelvhasználat, neveltetés - befolyásolja. Egy óvodás korú gyermek tévképzetei értelemszerűen más jellegűek mint egy végzős középiskolás tanulóé. A tanulmányunkban később bemutatott tévképzetek mind egységesen ugyanazokkal az általános jellemzőkkel bírnak, amelyeket az általános tévképzet fogalom meghatároz, de különböző specifikus tévképzet-csoportba sorolhatók be. Fontos azt is hangsúlyoznunk, hogy a tévképzetek elszigetelten jelennek meg, azaz nem nagy számban és nem mindenkinél ugyanolyan mértékben felbukkanó jelenségről van szó.

\section{Célkitüzések}

Magyarországon az 1990-es években indultak meg a kimondottan tévképzetekre vonatkozó kutatások. A legtöbb kutatás a fizika (Korom E. 2002, 2005; Korom E. - Csapó B. 1997; Radnóti K. 2005; Radnóti K. - Nahalka I. (szerk.) 2002), a kémia (Dobóné T. É. 2007; Juhász E. et al. 1999; Kluknavszky Á. 2006; Kluknavszky Á. - Tóth Z. 2009; Korom E. 2002, 2005; Korom E. - Csapó B. 1997; Ludányi L. 2007; Tóth Z. 1999a, 1999b) és a biológia (Banai V. 2004; Malmos E. - Revákné M. I. 2015; Nagyné 1999) tantárgyak tévképzeteit igyekezett feltárni. A földrajz tantárgyhoz kapcsolódó tévképzeteket kevesen vizsgálták eddig (DuDÁs E. 2008), ezért 2011-ben részletesebben tanulmányozni kezdtük a földrajz tantárgyhoz kapcsolódó tévképzeteket.

A teljes kutatásunk egy hat különböző korcsoportot (harmadik, ötödik, hetedik, kilencedik és tizenegyedik évfolyamos tanulók, illetve egyetemi hallgatók) tartalmazó projekt. Az adatok nagy mennyiségére való tekintettel három különböző célcsoport lemeztektonikával kapcsolatos tévképzeteit mutatjuk be ebben a cikkben. Az első csoport kilencedikes középiskolás tanulókból áll, a második földrajz szakos BSc hallgatókból, a harmadik BA képzésben részvevő bölcsészhallgatókból. Kutatásunk során az alábbi kérdésekre kerestük a választ:

1. Milyen lemeztektonikai tévképzeteik vannak a tanulóknak?

2. A talált tévképzetek melyik specifikus csoportba sorolhatók be?

3. Melyek a tanulók fő információforrásai a földrajzi ismeretek tekintetében?

\section{Adatgyüjtés és módszerek}

Kutatásunkban elsősorban kvalitatív tartalomelemzést végeztünk, amelyet kvantitatív módszerekkel egészítettünk ki. A 2012-ben felvett pilot-felmérést (N=139) 2013-ban 
egy szélesebb körü, az előzetes eredmények alapján módosított tartalmú felmérés ( $\mathrm{N}=1$ 111) követte. Nem valószínűségi mintagyüjtést alkalmaztunk, ugyanis reprezentatív minta felvételére nem állt rendelkezésünkre megfelelő háttér. Mintánk földrajz szakos és bölcsész (anglisztika és nemzetközi kapcsolatok) hallgatói a Szegedi Tudományegyetem hallgatói voltak, a középiskolás tanulók pedig egy kiskunhalasi középiskola kilencedik osztályos tanulói (2. táblázat).

\begin{tabular}{l|ll} 
Mintacsoport & Résztvevők száma & Mintacsoport átlagos életkora \\
\hline 9. o. középiskolai csoport $\left(\mathrm{N}_{9}\right)$ & 44 & 14,7 év \\
Földrajz szakos hallgatók $\left(\mathrm{N}_{\text {unigeo }}\right)$ & 49 & 22,3 év \\
Bölcsész hallgatók $\left(\mathrm{N}_{\text {uniarts }}\right)$ & 40 & 21,9 év
\end{tabular}

2. táblázat. A felmérésben résztvevő tanulók száma és átlagos életkora

A felmérés időpontjában (2012 ősze és 2013 tavasza) a kilencedikes tanulók már tanulták a lemeztektonikára vonatkozó témakört a középiskolában. A földrajz szakos hallgatók is letették már a kapcsolódó bevezető kurzusokból a vizsgáikat, a bölcsészhallgatók pedig nem részesültek kimondottan földrajzi irányultságú oktatásban a középiskola befejezése óta. A mérőeszköz a következő részekből állt: háttér-információs kérdőív, szóasszociációs feladatsor és egy nyílt végű kérdéseket tartalmazó feladatsor. Az így nyert adatokat a trianguláció elvét követve értékeltük.

\section{Szóasszociációs feladatsor}

A tanulóknak hat hívófogalomra - olyan földrajzi fogalom, amely része a kilencedik osztályos kerettantervnek - kellett szavakkal vagy rövid kifejezésekkel asszociálniuk. A hívófogalmak a következők voltak: a Föld belső szerkezete (A), hegységképződés (B), kőzetlemez (C), vulkán (D), földrengés (E), lemeztektonika (F). Elsőként az egyes hívófogalmakhoz tartózó összes asszociáció kvalitatív tartalomelemzését végeztük el mintacsoportonként. A Garskof-Houstonféle kapcsolati együttható ( $\mathrm{RC}$ ) alapján gráfokat szerkesztettünk, amelyek azt jelzik, hogy az asszociációk alapján mennyire erős a hívófogalmak közti kapcsolat, de a kapcsolat minőségi jellemzőire nem ad választ (GARsKof, B. E. Houston, J. P. 1963; Kluknavszky Á. - Tóth Z. 2009). Végül a hívófogalmak összes asszociációját gyakorisági eloszlás alapján működő program segítségével (FeInberg, J. 2010) vizualizáltuk. 


\section{Nyílt végü kérdések}

A részvevőknek hat nyílt végű kérdésre kellett válaszolniuk, amelyek a következők voltak:

1. Mi okozza a földrengéseket?

2. Verne Gyula Utazás a Föld középpontjába címü regényében a szereplők egy vulkán kürtőjén keresztül eljutnak egészen a Föld közepébe. Lehetséges-e ez? Indokold válaszodat! Rajzold le, és magyarázd el, hogyan történik egy vulkánkitörés!

3. Miért hasonlít egymáshoz Afrika nyugati partvonala és Dél-Amerika keleti partvonala? (Térkép volt a feladathoza hasonlóság szemléltetéséhez.)

4. Rajzold le, hogyan alakulnak ki a hegyek, és röviden magyarázd el!

5. Ha egy speciális lift segítségével eljuthatnál a Föld középpontjába, mit látnál utazásod során? Rajzold le, és pár szóval magyarázd el!

Az egyéni válaszok értékelésénél csoportonként folyamatos kvalitatív tartalomelemzést végeztünk. A kapott válaszokat egy 0-tól 5 pontig terjedő skála segítségével kategorizáltuk (AвraнAм, M. R. et al. 1992; idézi Korom E. 2002) (3. táblázat). Továbbá az egyéni válaszokat tartalmuk alapján besoroltuk a legmegfelelőbb specifikus tévképzet-csoportba, valamint lejegyeztük, van-e köztük olyan, ami csak arra a csoportra (életkorra) jellemző. A következő szempontok alapján soroltuk azokat csoportokba:

\begin{tabular}{l|ll}
\hline A megértés szintje & A pontozás kritériumai & A válasz pontértéke \\
\hline Nincs válasz & $\begin{array}{l}\text { Üres lap } \\
\text { „Nem tudom.” }\end{array}$ & 0 pont \\
& "Nem értem.” & \\
Nincs megértés & $\begin{array}{l}\text { A kérdés megismétlése. } \\
\text { Nem a tárgyhoz tartozó, értelmetlen válasz. }\end{array}$ & 1 pont \\
& $\begin{array}{l}\text { A tapasztalat megismétlése. } \\
\text { A válasz logikátlan és helytelen információt tartalmaz. }\end{array}$ & 2 pont \\
Tévképzet & A válaszok jelzik az adott fogalom megértését, de tartal- & 3 pont \\
tévképzettel & maznak olyan állításokat is, amelyek tévképzetre utalnak. & \\
Részleges megértés & $\begin{array}{l}\text { A válaszok a helyes válasz elemei közül legalább egyet } \\
\text { tartalmaznak, de nem az összeset. }\end{array}$ & 4 pont \\
& A válaszok a helyes megoldás összes elemét tartalmazzák. & 5 pont
\end{tabular}

3. táblázat. A nyílt végü kérdésekre adott válaszok kategorizálása (ABRAHAM, M. R. ET AL. 1992, idézi KoROM E. 2002) 
- Ha a helytelen válasz a magyar nyelv használatából adódott, akkor vernakuláris (köznyelvi) tévképzetként soroltuk be.

- Ha a helytelen válasz a magyar kultúrára volt visszavezethető, akkor kulturális tévképzetként azonosítottuk.

- Ha a helytelen válasz olyan elemeket tartalmazott, amelyekből arra következtettünk, hogy a tanuló nem értette meg egyáltalán vagy csak részben az adott lemeztektonikai jelenséget annak ellenére, hogy alapos formális oktatásban részesült, akkor fogalomalkotási tévképzetként azonosítottuk a választ.

- Ha a helytelen válasz legalább részben a média vagy regények, képregények, filmek, stb. hatását mutatta, akkor a populáris tévképzetekhez soroltuk.

Ha a helytelen válasz mindennapi tapasztalaton, megfigyelésen alapult tudományos magyarázat helyett, akkor prekoncepciónak neveztük. A nyílt végü kérdésekre adott válaszok részletes tartalmi elemzésével megbizonyosodhatunk arról, hogy a szóasszociációkban már felbukkanó, tévképzet meglétére utaló kifejezések valóban tévképzetek-e. Új tévképzetek is megjelenhetnek, valamint segítenek abban is, hogy megállapíthassuk, hogy a specifikus tévképzetek melyik típusáról van szó.

\section{Háttér-információs kérdöív}

A háttér-információs kérdőívben azt vizsgáltuk, honnan származnak a tanulók földrajzi ismeretei, és azok milyen hatással vannak a tévképzetek kialakulására. A diákoknak tíz információforrást kellett fontosságuk szerint besorolni, majd ezekre példákat kellett írniuk.

\section{Lemeztektonikai tévképzetek: hasonlóságok és különbségek}

A szóasszociációs feladatsor kvalitatív tartalmi elemzésekor azt tapasztaltuk, hogy mindhárom csoportnál felbukkannak olyan kifejezések, amelyek tudományos szempontból hibásak. Így önmagukban azonban még nem nevezhetők tévképzetnek. A két leggyakoribb helytelen kifejezés a „felgyürődés” és a „kontinensvándorlás” szavak voltak. A földrajz szakos egyetemi hallgatók asszociációi tudományosabbak és szakszerübbek voltak, mint a másik két csoport asszociációi. Ugyanakkor szintén ők voltak azok, akik filmekre utaló asszociációkat is írtak (2012, Jégkorszak 4., A mag), amit a másik két csoportnál nem tapasztaltunk.

A kapcsolati együttható (RC) alapján szerkesztett gráfok (1., 2. és 3. ábrák) jól szemléltetik, hogy az asszociációk alapján milyen erős a hívófogalmak közötti kapcsolat, de annak minőségi 
jellemzőire nem ad választ. A középiskolás tanulók és a földrajz szakos egyetemi hallgatók gráfján (1. és 2. ábra) látható, hogy minden fogalom kapcsolatban áll egymással (helyesen). A bölcsészhallgatók esetében (3. ábra) viszont a kőzetlemez (C) és a vulkán (D) hívófogalmak között viszont nincs megjelenített kapcsolat, ami arra enged következtetni, hogy a közetlemezek mozgásait nem tartják (szorosan) összetartozónak a vulkanizmus jelenségével.

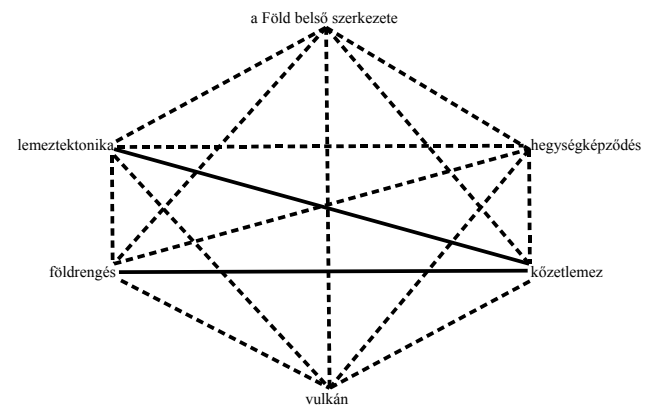

1. ábra. Kilencedik évfolyamos középiskolás tanulók kapcsolati együtthatói alapján szerkesztett gráfia Jelkulcs: folytonos vonal - nagy RC, szaggatott vonal - közepes $R C$

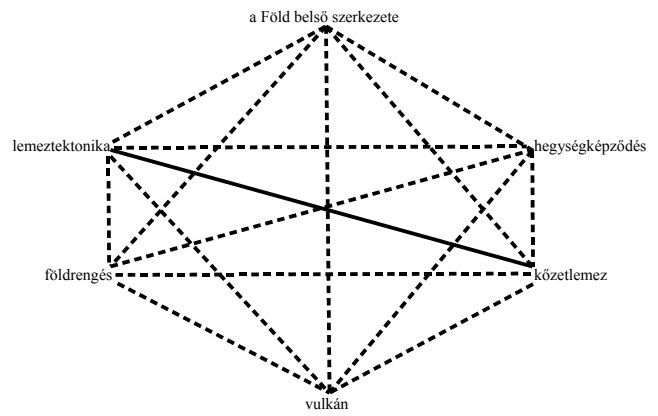

2. ábra. Földrajz szakos egyetemi hallgatók kapcsolati együtthatói alapján szerkesztett gráfja Jelkulcs: folytonos vonal - nagy RC, szaggatott vonal - közepes $R C$

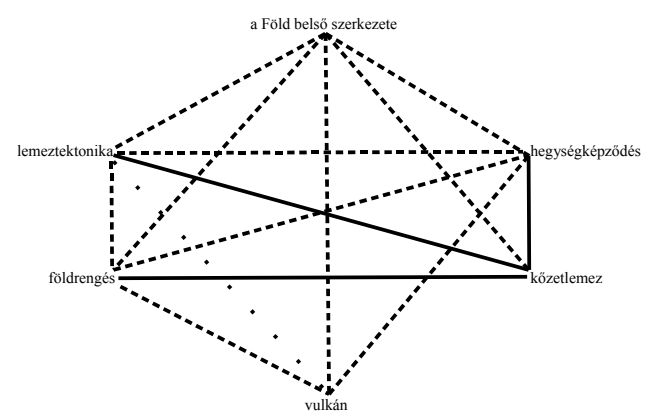

3. ábra. Bölcsészhallgatók kapcsolati együtthatói alapján szerkesztett gráfja. Jelkulcs: folytonos vonal nagy $R C$, szaggatott vonal - közepes $R C$, pontozott vonal - kis $R C$ 
Mindhárom csoportban a lemeztektonika - kőzetlemez párosnak lett a legmagasabb a kapcsolati együttható (RC) értéke, azaz leginkább összetartozónak ezt a két fogalmat érezték a tanulók. A bölcsészhallgatók esetében viszonylag alacsony kapcsolati értékekkel jellemezhető a vulkán - földrengés (DE), a vulkán - lemeztektonika (DF) és a földrengés - lemeztektonika (EF) hívószó-párok is. Ez viszont nem feltétlenül jelzi azt, hogy a bölcsészhallgatók a kőzetlemez - vulkán (CD) hívófogalmakhoz hasonlóan nem tartják összetartozónak ezeket a földtani jelenségeket. Erre a nyílt végű kérdések elemzésével kapunk választ.

Az 4., 5. és 6. ábrák a három csoport földrengés hívószóra adott össze asszociációinak gyakorisági eloszlásait szemléltetik szófelhők formájában. Ezek elkészítéséhez FeINBERG, J. (2010) Wordle applikációját használtuk.

Feinberg információ-vizualizációs technikája is jól szemlélteti, hogy a földrajz szakos hallgatók adták a legtöbb asszociációt, és a három csoport közül ők használták a legtöbb szakmai kifejezést. Az asszociációk egyaránt származhatnak a tananyagból (például Richter-skála, kőzetlemez, epicentrum, hipocentrum), valamint esetleg informális információforrásból (média) is (például Japán, Fukushima, cunami).

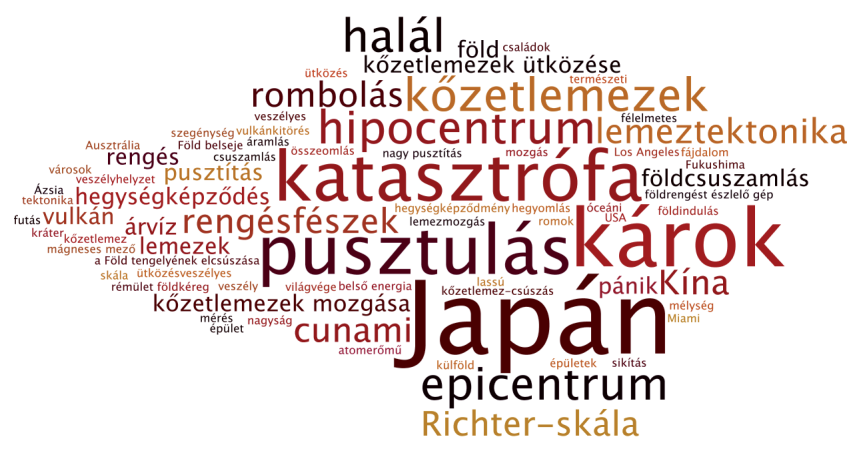

4. ábra. Kilencedik évfolyamos középiskolás tanulók földrengés hívószóra adott asszóciációi alapján szerkesztett szófelhö

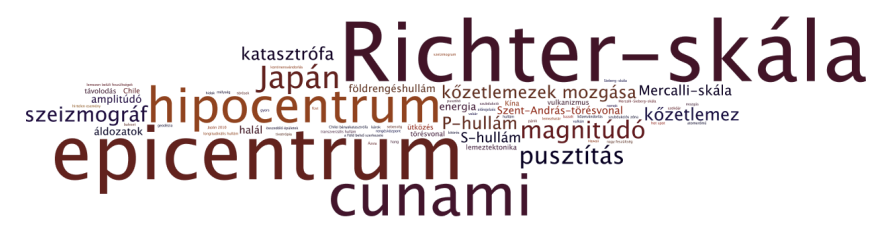

5. ábra. Földrajz szakos egyetemi hallgatók földrengés hívószóra adott asszóciációi alapján szerkesztett szófelhö 


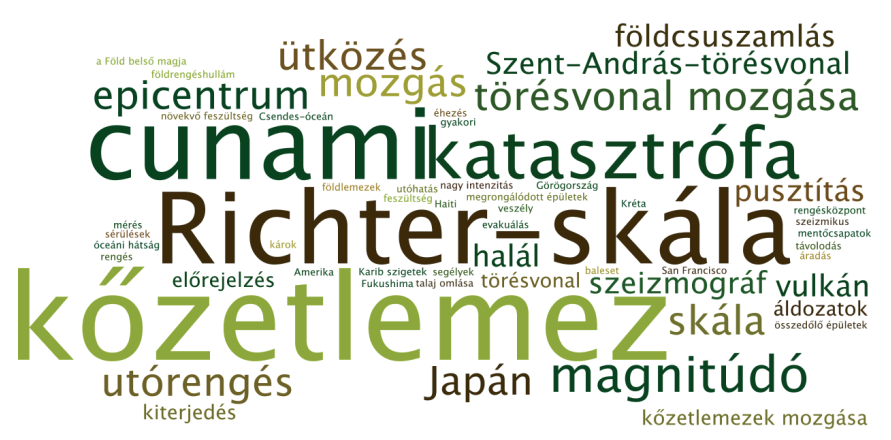

6. ábra. Bölcsészhallgatók földrengés hivoószóra adott asszóciációi alapján szerkesztett szófelhő

A 7. ábrán a tévképzetek ( 2 pont) és a részleges megértés tévképzettel (3 pont) kategóriák összesített eloszlása látható az összes kérdésre adott és tévképzetként azonosított válaszok közül. A földrajz szakos hallgatóknak van a legkevesebb tévképzetük (6\%), de a 9-es középiskolás diákok szintén kevés tévképzettel (7\%) rendelkeznek. Ezzel szemben a bölcsészhallgatók körében a tévképzetek aránya már 13\%-ra nő. A három pontos válaszok, tehát a részleges megértés tévképzettel kategória viszont már jelentős növekedést mutat nemcsak a bölcsészhallgatók (26\%), hanem a földrajz szakos hallgatók között is (16\%). Egyedül a középiskolások csoportjában marad ez a kategória is alacsonyan (7\%).

A 8. és a 9. ábrán a hat kérdésre adott válaszok közül a 2 és 3 pontos kategóriába (tévképzet, részleges megértés tévképzettel) került feleletek megoszlása látható mindhárom csoport esetén.

A földrengések lehetséges okaként a földrajz szakos hallgatók adták a legtöbb tévképzetként azonosított választ, például: „a kőzetlemezek kis darabokra törnek”, ezért vannak földrengések, vagy „a Föld belső nyomása okozza a földrengéseket”.

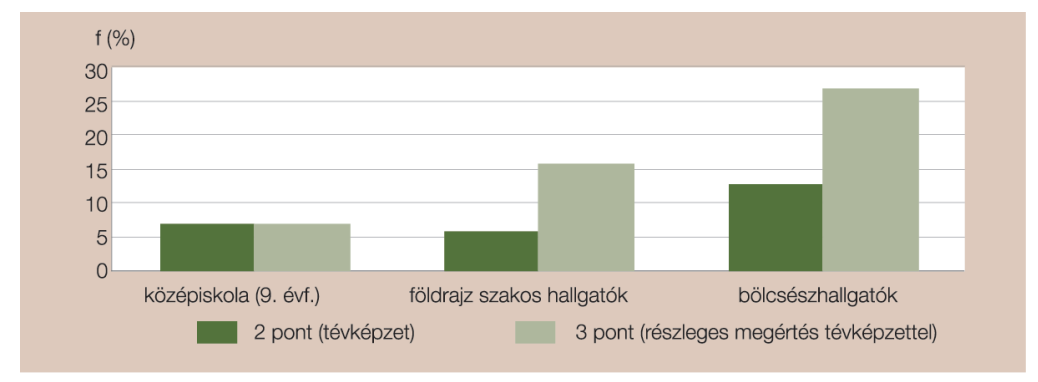

7. ábra. A három csoport tévképzet és részleges megértés tévképzettel kategóriákba sorolt válaszainak százalékos megoszlása 


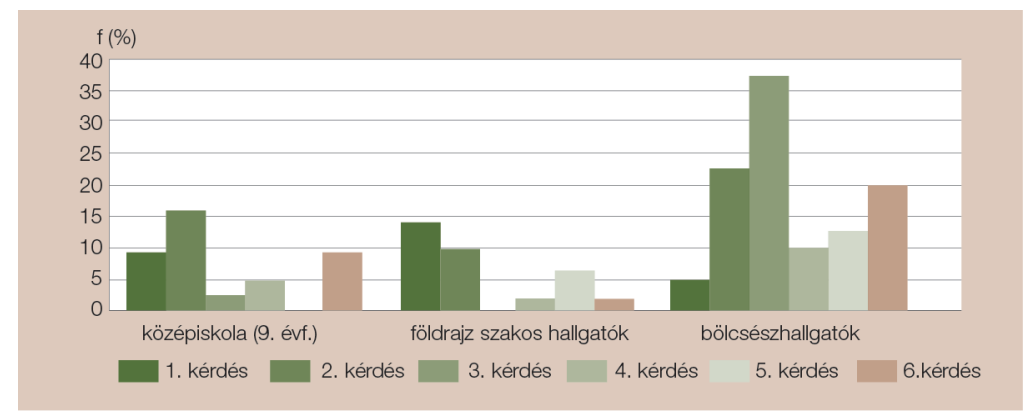

8. ábra. A tévképzetként azonosított válaszok százalékos megoszlása

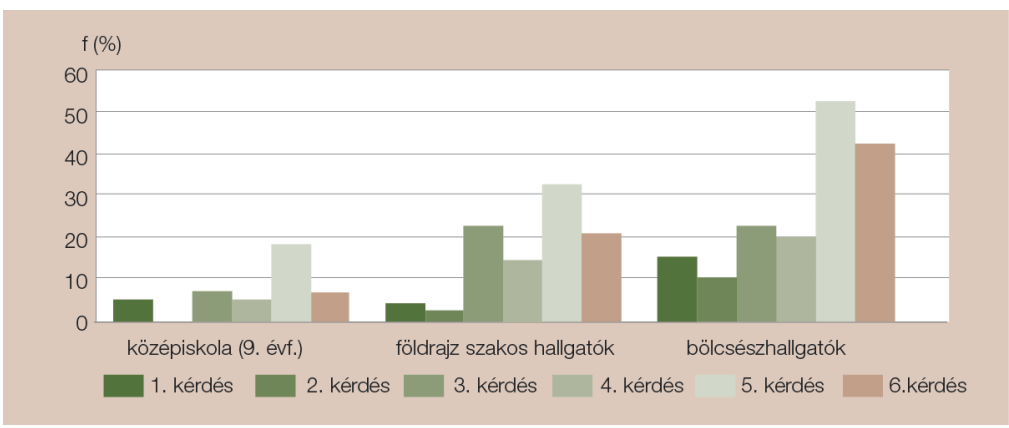

9. ábra. A részleges megértés tévképzettel kategória százalékos megoszlása

Minden csoportban megtalálható volt az az általános tévképzet, hogy a földrengéseket „A Föld belsejéből származó valamilyen energia” okozza. További tévképzetek voltak, de minden csoportban csak egyénileg fordultak elő, a következő válaszok: A földrengéseket „a Föld tengelyének csúszása” (9. osztály), „földlemezek” (bölcsészhallgató), „talaj összeomlása” (bölcsészhallgató) okozza. A talált tévképzetek nem jelentek meg a szóasszociációkban.

A talált tévképzeteket fogalomalkotási tévképzetként azonosítottuk, mert a válaszokból arra következtettünk, hogy a tanulók nem helyesen építették be a földrengésekről tanultakat a maguk belső ismeretrendszerébe, tehát a fogalmi váltás nem volt sikeres. Használtak ugyan tudományos kifejezéseket, de azok pontossága nem volt megfelelö.

Verne regényhőseihez hasonlóan voltak tanulók, akik úgy vélték, lehetséges a földmagba vulkáni kürtőn keresztül eljutni. A kilencedikes tanulók és a bölcsészhallgatók tévképzetei hasonlóak voltak egymáshoz: 1. a vulkánok elérhetik egészen a Föld magját, mert 2. a magma és/vagy a láva a Föld magjából származik. Ezek a válaszok 
fogalomalkotási tévképzetek jelenlétére utalnak, hiányzik a vulkanizmus folyamatának, a Föld belsőszerkezetének, valamint a magma és a láva közti különbség megértése, noha ez része a középiskolás tananyagnak. Szintén felbukkant egy bölcsészhallgatónál az a tévképzet, hogy „a Föld belseje folyékony”. A válaszok közül egyedül a „folyékony” szó bukkant fel a szóasszociációkban. A földrajz szakos hallgatóknak kevesebb tévképzetük volt, az ő tévképzetként azonosított válaszaikat a következők jellemezték: „lehetetlen információt gyưjteni a Föld belső szerkezetéröl”, és két válasz azt sejtette, hogy a vulkáni kürtőkön el lehet érni a Föld középpontját, amelyek szintén fogalomalkotási tévképzetek.

A vulkánok működésére vonatkozó kérdés esetén a tévképzetek (a 2 pontos válaszok) gyakorisági eloszlása a bölcsészhallgatók között volt a legmagasabb, a középiskolás diákoknak kevés, a földrajz szakos hallgatóknak pedig egy tévképzetük sem volt. A 3 pontos válaszok (tévképzet részleges megértéssel) aránya ugyanolyan volt mindkét egyetemi csoport körében, egyedül a középiskolások mutatták a vulkanizmus nagyfokú részleges vagy teljes megértését. A következő tévképzeteket találtuk: „a láva a Föld belső magjából származik” (középiskola), ,a kőzetlemezek a magas hőmérséklet miatt mozognak” (középiskola), a magma és a láva ugyanaz (földrajz szakos és bölcsészhallgatók), a magma/láva a litoszféra alól származik (földrajz szakos és bölcsészhallgatók), „a magma gáz formájában éri el a Föld felszínét” (földrajz szakos hallgató), „,a kőzetlemezek a vulkánkitörések miatt mozognak" (bölcsészhallgató), a vulkánok és a gejzírek müködési mechanizmusának keverése (bölcsészhallgató). A szóasszociációkban nem fordult elő tévképzetre utaló kifejezés. Ezek a tévképzetek szintén a fogalomalkotási tévképzet csoportba sorolhatók.

A két kontinens partvonalának hasonlóságát firtató kérdésünkre mindhárom csoport esetében a „kontinensvándorlás” volt a leggyakoribb tévképzet vagy részleges megértés tévképzettel kategóriába sorolható válasz. Ez volt az a kifejezés is, amely mindhárom csoport szóasszociációiban gyakran elöfordult. A következő egyéni tévképzeteket találtuk: „a tenger hullámzása okozza a kontinensvándorlást” (bölcsészhallgató), „a földrengések okozzák a kontinensvándorlást” (bölcsészhallgató), és „kőzetek okozzák a kontinensvándorlást" (bölcsészhallgató). Mind a kontinensvándorlást, mind a felsorolt okokat a fogalomalkotási tévképzet kategóriába soroltuk.

A hegységképződés folyamatára adott leggyakoribb válasz a felgyürődés volt mindhárom csoportban. Ezt a tévképzetet vernakuláris csoportba soroltuk, azaz magyar nyelvhasználati sajátosságból eredő tévképzetként, amely azonban megtalálható egy akkor széles körben használt középiskolás tankönyvben is. A felgyürődést csak akkor 
soroltuk a 2 pontos válaszok közé, ha hiányzott a magyarázatokból és/vagy a rajzokból a hegységképződés alapvető folyamatának a megértése. Ha a magyarázatok és a rajzok jelezték, hogy a folyamatot az adott tanuló megértette, akkor a tévképzet mellett az adott jelenség részleges megértése megtörtént, így 3 pontot kapott. Fogalomalkotási tévképzetként azonosítottuk a következő válaszokat: „a kőzetlemezek összegyűrődnek” (földrajz szakos és bölcsészhallgató), „a hegységképződést földrengések okozzák” (bölcsészhallgató), ,az egyik kőzetlemez felemeli a másikat” (középiskola). A felgyűrődés szó jelent meg a leggyakrabban a hegységképződés, a kőzetlemez és a lemeztektonika hívófogalmakra adott válaszok között, és a Garskof-Houston-féle kapcsolati együttható értéke is e három hívófogalom között volt a legerősebb (1., 2. és 3. ábra).

A Föld belső felépítését leíró válaszok mutatták a legnagyobb változatosságot a tévképzetek terén. Általában véve kevesebb teljesen tévképzet válasz született, mint részleges megértés tévképzettel. A 3 pontos válaszok (tévképzet részleges megértéssel) gyakorisági eloszlása a bölcsészhallgatók körében volt a legmagasabb. A szóasszociációkban nem volt tévképzetre utaló kifejezés. A magma és a láva kifejezések ugyan megjelentek, de a nyílt végü kérdésekre adott válaszok ezek tévképzeti jellegét itt nem erősítették meg. A következő fogalomalkotási tévképzeteket azonosítottuk: „a Föld magja folyékony” (mindhárom csoport), „a magma litoszféra alatt található” (középiskola, bölcsészhallgató), a kőzetburok és a köpeny keverése (középiskola, bölcsészhallgató), az asztenoszféra anyaga a magma (bölcsészhallgató), „a belső mag folyékony, a külső mag szilárd” (bölcsészhallgató), több kőzetburok is van (bölcsészhallgató), „a forró pontos vulkanizmus a magból ered" (földrajz szakos hallgató).

A szóképzetekben felbukkanó tévképzetgyanús kifejezések nem minden esetben bizonyultak annak a nyílt végű kérdésekre adott válaszok elemzése után. Ez fordítva is igaz: voltak olyan asszociációk, amelyek helyesen tủntek fel egy-egy adott hívófogalomhoz kapcsolódóan (például vulkán-láva), de később láthattuk, hogy egy-egy tanulónak helytelen elképzelése, tévképzete van a láva származásával kapcsolatban, azaz fogalomalkotási problémája van. Mivel a tévképzetek olyan kognitív struktúrák, amelyek mélyen be vannak ágyazódva az emberek ismeretrendszerébe, nehezen változtathatók meg, és hosszú ideig megmaradnak (KoROM E. 2002, 2005), a három csoport válaszainak hasonlóságából arra következtethetünk, hogy a talált tévképzetek esetlegesen már középiskolás korból származnak, ahol is a tananyag nagy terjedelme és a tantárgy alacsony óraszáma miatt nem elég az idő arra, hogy a tanulók fogalmi szerkezete helyesen stabilizálódjon, a fogalmi váltás nem sikeres, ezért magas a fogalomalkotási tévképzetek aránya. 
Feltételezésünk szerint a tanulók földrajzi ismereteinek forrásai hatással lehetnek a tévképzetek kialakulására. Hogy ezt megismerjük, a diákoknak tíz információforrást kellett sorrendbe tenniük fontosságuk szerint, majd ezekre példákat kellett írniuk. Az információforrások összesített sorrendje a 10. ábrán látható. Az összes információforrások közül a tanári magyarázat áll az első helyen mindhárom csoportnál. Ezt követi a tankönyv második helyen, majd az atlaszok a harmadik helyen. E három információforrás sorrendisége jelzi, hogy kiemelkedő jelentőségű az, hogy mit, miből és hogyan tanítunk. Ezekből következően pedig a tanárképzés és a tankönyvfejlesztés az a két terület, amelynek kiemelkedő fontosságúnak kell lennie, ugyanis nem minden tanár tanít egyformán jól, és nem minden könyv egyformán jó. Mivel minden csoportnál a formális információforrások szerepe a legfontosabb, feltételezhető, hogy a tévképzetek kialakulásában szerepet játszhat a nem megfelelő módon, vagy a nem megfelelő könyvből megtanított tananyag is. Ennek kutatására ugyanakkor más típusú adatfelvételre van szükség, és számos egyéb tényező (például szövegértés, egyéni érdeklődés, egyéni tanulási technikák) is befolyásolhatják a fogalmi váltás sikerességét, de sikertelenségét is, ezzel a tévképzetek kialakulását. Mindenképpen fontosnak tartjuk a földrajzi tartalmak hosszabb ideig tartó bevésését, a helyes fogalmi rendszerek kialakítására szánt időt, valamint a változatos tanítási technikákat alkalmazó tanárok földrajzi és oktatásmódszertani felkészültségét.

A három formális információforrást szorosan követi korunk két jelentős hatású informális forrása: a televízió és az Internet. Célzott internetes keresés esetén a Google Earth és a Wikipedia a leggyakrabban használt információforrás. A diákok

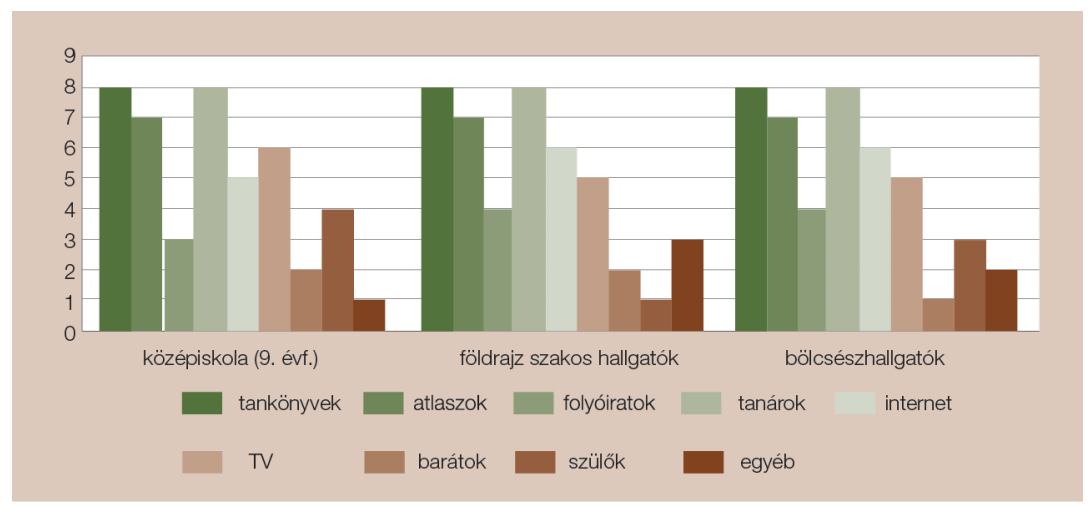

10. ábra. A három csoport információforrásainak sorrendje 
elhanyagolható része ellenőrzi azt, hogy az általa talált információ tudományos szempontból megbízható-e, ez inkább a földrajz szakos hallgatókra volt jellemző. A jelenleg oktató földrajztanároknak (is) éppen ezért naprakésznek kell lenniük a tantárgy tudományterületén történő változásoknak, új felfedezéseknek, elméleteknek, hogy korszerü ismereteket adhassanak át tanítványaiknak. Hasonlóan fontos az is, hogy megtanítsák diákjaikat az információ ellenőrzésére és szelektálására, hogy a diákok képesek legyenek különbséget tenni az áltudományos hírek és a valódi tudományos eredmények között, valamint hogy megtalálják azokat a hiteles, tudományos forrásokat, amelyek alapján az érdekesnek vélt földrajzi információ helyességét ellenőrizni tudják. Ezzel is csökkenthető a tévképzetek kialakulásának esélye.

\section{Összegzés}

Kutatásunk céljai a következők voltak: lemeztektonikai tévképzetek azonosítása középiskolások és egyetemi hallgatók körében; a talált tévképzetek különbségeinek meghatározása; valamint a tévképzetek és a földrajzi információforrások kapcsolatának vizsgálata.

Mindhárom vizsgált csoportnak hasonló tévképzeteik voltak a hegységképződést, a vulkáni tevékenységet és a kőzetlemezek mozgását tekintve. Ezek a tévképzetek valószínüleg nem az egyetemi évek alatt alakultak ki a hallgatókban, hanem korábban, még a középiskolában (vagy még azelőtt), azaz a diákok fogalmi váltása nem volt sikeres, és a meglévő tévképzetek túl mélyen rögzültek az ismeretrendszerükben. Mivel a tévképzetek általában véve akadályt jelentenek a tanulásban, így a földrajz tanulásában és tanításában is, fontos, hogy a tanárok tisztában legyenek azzal, hogy maguk a tévképzetek valós problémát jelentenek. Egy tévképzet nem egyszerüen a tudás hiányát jelzi, hanem olyan kognitív akadályt, amely mélyen gyökerezik, és még a pontos, alapos tanítás sem tudja esetenként felülírni. A földrajz tantárgy (valamint a környezetismeret és a természetismeret tantárgyak) alacsony óraszáma, de hatalmas lexikális anyaga jelentőségteljesen lerövidíti a bevésődésre fordított időt. Mindez előrevetíti azt, hogy a fogalmi váltás, amely az ismeretrendszer átszerveződését (felülírását) jelentené ideális esetben, nem vagy pontatlanul fog megtörténni. Ez az elsődleges oka a tévképzetek megjelenésének itt Magyarországon.

A talált tévképzetek elsősorban fogalomalkotási tévképzetek voltak a felgyürődés kivételével, amely egy vernakuláris tévképzet. A vernakuláris vagy köznyelvi tévképzetek 
a nyelvhasználatból fakadnak, ezért a tanároknak és a tankönyvíróknak egyaránt nagy gondot kell fordítaniuk mind az írott, mind a beszélt nyelv használatára. Kulturális tévképzetet nem találtunk, sem olyat, amelyet a média, a kortárs irodalom vagy filmek, vagy a televízió erőteljesen befolyásolt volna.

A televízió és az internet mint informális információforrások szerepe egyre nő. Célravezetőbb arra megtanítani a diákokat, hogy ezeket az információforrásokat okosan használják, tartalmuk iránt kritikával éljenek, és tanulják meg az onnan nyert információhalmazt szelektálni és értékelni. Tanárként és kutatóként is egyaránt fontos feltérképezni a tanulók ismeretrendszerét, amelyre a szóasszociációk, és az azok alapján szerkesztett szófelhők motiváló infokommunikációs eszközként jelennek meg. A nyílt végü kérdésekre adott válaszok jelzik a szövegértés fontosságát is. Bár ezt kutatásunk nem mérte, mégis úgy gondoljuk, hogy komoly probléma lehet a diákok, hallgatók szövegértésével. A nem megfelelő szövegértés is okozhatja a fogalmi váltás félresiklását és a tévképzetek kialakulását.

Kiinduló kutatásunk számos további kutatási irányt felvet. Eredményeink megerősítik azt, hogy a szövegértés és tévképzetek kialakulása közötti kapcsolatot mélyrehatóan lenne érdemes tanulmányozni. Az információforrások szerepét is szélesebb körben, interjúk segítségével alaposabban fel lehet tárni. Fontosnak tartjuk azt, hogy a tanítási módszerek eredményességét, valamint a tanulók tanulási technikáit is megismerjük, és ezek ismeretében maga a tanárképzés is megújuljon. Végül ugyanolyan fontosnak tartjuk azt is, hogy kutatásunk ismeretében jobban elgondolkodjunk azon - függetlenül attól, hogy általános iskolásokat, középiskolásokat vagy egyetemistákat tanítunk -, milyen földrajzi tartalmat milyen életkorban és mennyi időn át érdemes megtanítani, ha azt szeretnénk elérni, hogy diákjaink hasznos, milyen módszerrel és használható földrajzi ismeretekkel rendelkezzenek, lehetőleg minél kevesebb tévképzettel.

\section{Irodalom}

AвRAнам, M. R. et al. 1992: Understandings and misunderstandings of eighth graders of five chemistry concepts found in textbooks. Journal of Research in Science Teaching, 29(2), pp. 105-120. DOI: https://doi.org/10.1002/tea.3660290203

Alsparslan, C. - Tekraya, C - Geban, O. 2003: Using the conceptual change instruction to improve learning. Journal of Biological Education, 37(3), pp. 133-137. DOI: https://doi.org/10.1080/00219266.200 3.9655868 
BANAI V. 2004: Mit tudnak a tanulók a gyógynövényekről? A Biológia Tanítása, 12(1), pp. 15-30.

Barnett, M. - Wagner, H. - Gatling, A. - Anderson, J. - Houle, M. - Kafka, K. 2006: The impact of science fiction film on student understanding of science. Journal of Science Education and Technology, 15(2), pp. 179-191. DOI: https://doi.org/10.1007/s10956-006-9001-y

Chang, C. H. - Pascua, L. 2015: 'The hole in the sky causes global warming': A case study of secondary school students' climate change alternative conceptions. Review of International Geographical Education Online, 5(3) pp. 316-331.

DовóNÉ T. É. 2007: Általános iskolai tanulók tudásszerkezete: Az anyag és az anyag változásai. Iskolakultúra, 17(8-10), pp. 221-233.

Dolphin, G. - Benoit, W. 2016: Students' mental model development during historically contextualized inquiry: how the "tectonic plate" metaphor impeded the process. International journal of Science Education, 38(2), pp. 276-297. DOI: https://doi.org/10.1080/09500693.2016.1140247

DudÁs E. 2008: Tévképzetek a középiskolai földrajztanulás során. Szakdolgozat - kézirat. Szegedi Tudományegyetem, szeged, p. 72.

Eryilmaz, A. 2002: Effects of conceptual assignments and conceptual change discussions on students' misconceptions and achievement regarding force and motion. Journal of Research in Science Teaching, 39(10), pp. 1001-1015. DOI: https://doi.org/10.1002/tea.10054

FeinberG, J. 2010: Wordle. In julie steele \& noah iliinsky (eds.) Beautiful visualization: looking at data through the eyes of experts (pp. 37-58). Sebastopol, CA: O'reilly Media, inc.

Garskof, B. E. - Houston, J. P. 1963: Measurement of verbal relatedness: an idiographic approach. Psychological Review, 70(3) pp. 277-288. DOI: https://doi.org/10.1037/h0041879

Juhász E. - Márkus E. - Szabó, I. 1999: Természettudományos tévképzetek iskolai vizsgálata. Iskolakultúra, 9(10), pp. 97-103.

KLuknavszky Á. 2006: A folyadékok szerkezetéről alkotott tanulói elképzelések. A kémia tanítása, 14(4), pp. 19-27.

KLuknavszky Á. - Tóтн Z. 2009: Tanulócsoportok levegőszennyezéssel kapcsolatos fogalmainak vizsgálata szóasszociációs módszerekkel. Magyar Pedagógia, 109(4), pp. 321-342.

Korom E. - CsApó B. 1997: A természettudományos fogalmak megértésének problémái. Iskolakultúra, 7(2), pp. 12-20.

Korom E. 1999: A naiv elméletektől a tudományos nézetekig. Iskolakultúra, 9(10), pp. 60-71.

Когом E. 2000: A fogalmi váltás elméletei. Magyar Pszichológiai Szemle, 55(2-3), pp. 179-205. DOI: https://doi.org/10.1556/MPSzle.55.2000.2-3.2

Korom E. 2002: Az iskolai tudás és a hétköznapi tapasztalat ellentmondásai. In: Csapó B. (Szerk.), Az iskolai tudás. Osiris kiadó, Budapest. pp. 97-131.

Korom E. 2005: Fogalmi fejlődés és fogalmi váltás. Műszaki Könyvkiadó, Budapest, 192 p.

Kunn, T. S. 1962: The structure of scientific revolutions. Chicago Press, Chicago, 264 p. 
LUDÁNYI L. 2007: A levegő összetételével kapcsolatos tanulói koncepciók vizsgálata. Iskolakultúra, 17(10), pp. 117-130.

Malmos E. - RevÁKnÉ M. I. 2015: Biológia fogalmakhoz kapcsolódó tévképzetek vizsgálata szóasszociációs módszerrel. Iskolakultúra, 25(5-6), pp. 190-199.

Murphy, P. K. - Alexander, P. A. 2008: The role of knowledge, beliefs, and interest in the conceptual change process: a synthesis and meta-analysis of the research. In stella vosniadou (ed.), International handbook of research on conceptual change (pp. 583-616.) New york-London: Routledge.

NAGY L. 1999: Hogyan sajátították el a tanulók “az élővilág és a környezet” témakör anyagát? Egy fogalomfejlődési vizsgálat tanulságai. Iskolakultúra, 9(10), pp. 86-96.

National research council 1997: Science teaching reconsidered: a handbook. The National Academies Press, Washington, DC, $104 \mathrm{p}$.

Nieswandt, M. 2001: Problems and possibilities for learning in an introductory chemistry course from a conceptual change perspective. Science Education, 85(2), pp. 158-179. DOI: https://doi. org/10.1002/1098-237X(200103)85:2<158::AID-SCE40>3.0.CO;2-3

PARK, J. - HAN, S. 2002: Using deductive reasoning to promote the change of students' conceptions about force and motion. International Journal of Science Education, 24(6), pp. 593-609. https://doi. org/10.1080/09500690110074026

Pfundt, H. - Duit, R. 2009: Students' and teachers' conceptions and science education. A bibliography. Source: www.ipn.uni-kiel.de/aktuell/stcse/stcse.html Date of access: 11 December 2011

Pozo, J. I. 1997: A fogalmi váltás: Az újraszerkesztés, kifejtés és hierarchikus beépülés folyamata. Iskolakultúra, 7(12), pp. 47-57.

RADNóTi K. 2005: A fizika tantárgy problémái és lehetséges megoldások egy felmérés tükrében. A fizika tanítása, 13(3), pp. 5-13.

RADNóti K. - NAhalKa I. (Szerk.) 2002: A fizikatanítás pedagógiája. Nemzeti tankönyvkiadó, Budapest, $320 \mathrm{p}$.

Ross, K. E. K. - Shuell, T. J. 1990: The earthquake information test: validating an instrument for determining student misconceptions. Paper presented at the annual meeting of the northeastern educational research association, Ellenville, NY, October 31 - November 2, 1990.

Samarapungavan, A. - Vosniadou, S. - Brewer, W. F. 1996: Mental models of the earth, sun, and moon: indian children's cosmologies. Cognitive development 11(4), pp. 491-521. DOI: https://doi.org/10.1016/ S0885-2014(96)90015-5

Schur, Y. - SkUy, M. - Zietsman, A. - Fridjhon, P. 2002: A thinking journey based on constructivism and mediated learning experience as a vehicle for teaching science to low functioning students and enhancing their cognitive skills. School Psychology International, 23(1), pp. 36-67. DOI: https://doi. org $/ 10.1177 / 0143034302023001730$

Sungur, S. - Tekkaya, C. - Geban, O. 2001: The contribution of conceptual change texts accompanied 
by concept mapping to students' understanding of the human circulatory system. School Science and Mathematics, 101(2), pp. 91-101. DOI: https://doi.org/10.1111/j.1949-8594.2001.tb18010.x

Tóтн Z. 1999A: Egy kémiai tévképzet nyomában. Iskolakultúra, 9(2), pp. 108-112.

То́тн, Z. 1999B: A kémiatankönyvek mint a tévképzetek forrásai. Iskolakultúra, 9(10), pp. 103-108.

Vosniadou, S. - Brewer, W. F. 1992: Mental models of the earth: a study of conceptual change in childhood. Cognitive Psychology 24(4), pp. 535-585.

Vosniadou, S. - Vamvakoussi X. - Skopeliti I. 2008: The framework theory approach to the problem of conceptual change. In stella vosniadou (ed.), International handbook of research on conceptual change. New York \& London, Routledge. pp. 3-34. DOI: https://doi.org/10.1016/0010-0285(92)90018-W

A kutatás az MTA Tantárgy-pedagógiai Kutatási Program (2016-2020) támogatásával valósult meg. 